\title{
Effectiveness of Comics to Train Students' Critical Thinking Skills in Physics Learning: A Mini-Review
}

\author{
${ }^{*}$ S Khoiriyah ${ }^{1}$, N Suprapto ${ }^{1}$ \\ 1Department of Physics, Faculty of Mathematics and Natural Science, Universitas Negeri Surabaya, Surabaya 60231, \\ Indonesia
}

\begin{tabular}{l} 
Article Info \\
\hline Article history: \\
Received November 11, 2020 \\
Revised December 17, 2020 \\
Accepted January 4, 2021 \\
Available Online January 5, \\
2021
\end{tabular}

\section{Keywords:}

Critical Thinking

Comic Physics

Learning

\begin{abstract}
Critical thinking skills, namely intelligence, is needed by students in the 21st century period. Interpretation, analysis, evaluation, conclusions, and explanations are some of the cognitive indicators of critical thinking. One way to practice impressive critical thinking skills is to use comics as media. Comics are one of the benefits of improving the learning process because they have several aspects that can attract students' learning interest to understand the material to be conveyed through visualizing images and stories in comics. The research was intended to explain comic media's effectiveness to train students' critical thinking skills in learning physics. The research used a literature search in journals that can be accounted for in comic media and critical thinking skills. Data analysis techniques in library research applied descriptive qualitative research. Physics comics that are digital-based can attract students' interest because they can be used anytime and anywhere to strengthen students' critical thinking skills. The learning outcomes of students can be more effective and contextual. The literature search results obtained indicate that comic media is useful in training students' critical thinking skills.
\end{abstract}

https://doi.org/10.46627/silet

\section{INTRODUCTION}

In the 21st century, globalization and technology have a vital role in improving students' artistic skills and knowledge. The 21st century has an educational element that concerns student competencies, organization skills, collaboration, communication, and critical thinking. Expertise in critical thinking is needed to become a scientific behavior that exists in science. However, students' critical thinking skills are very lacking in classroom learning. Many students lack in thinking logically and solving the problems they face. Several steps can be taken to optimize crit is the use of interactive media arts. If there is a lack of interactive media in the learning process, then the learning process is not running optimally to meet the learning needs of students. According to the Regulation of the Minister of Education Number 41 of 2017, explains that learning is expected to take place actively, productively, interestingly, challenges, and gives students the ambition to participate in creating freedom according to what they can and the physical, mental growth of the students. Based on the implementation of the 2013 curriculum, learning activities are designed using critical thinking methods, and scientific approaches, namely the learning process is carried out by observing, concluding, and creating activities.

Critical thinking is reflective thinking in making decisions and problems analyzing situations, discussing problems, and thinking. Indicators of critical thinking are interpretation (classification and detection of information), argument evaluation, argument analysis, experimental data and considering the credibility of information evidence, inference (analyzing results and justification procedures), analyzing conclusions, hypotheses and truths, and setting. Students critically think because they carry out various school activities, all of which are done 
with careful thinking, strong arguments, and correct information. However, many students have not used thinking skills in dealing with school problems, causing students to be unable to solve the problem themselves and tend to need other people. To overcome this problem, some researchers use a method by presenting learning media that can attract students' interest in the learning process using comics. Comic media in learning will usually be packaged in an attractive and interactive appearance, not using textbooks but based on online media using KVisoft FlipBook Flash to prohibit student interest in learning.

Learning Physics is learning that requires self-readiness from students. Physics is one of the branches of science with three essential essences: physics as a product, as an attitude, and as a process. The thinking of high school students states that physics is a significantly less exciting subject. In physics learning, the teacher only explains the formulas and materials to develop learning and creates students' incomprehension. However, learning Physics also needs to apply a concept in everyday life and develop critical thinking skills. So that students can overcome various misconceptions in learning physics. It is vital to know how to solve students' learning physics and critical thinking skills using interactive and exciting learning media.

The essence of physics in a lesson can be interpreted directly by students by applying a scientific attitude. These results have an impact on students being able to conclude their physics learning that has been taught. With the media used and the use of exciting and creative methods, physics learning can run conducive. So far, the Teacher-Centered method has resulted in passive students, and students' learning independence is low so that students do not explore their abilities, only depending on the teacher. So that with the existence of comic media in learning physics, students imagine everyday life in understanding physics material. Physics material will be more enjoyable with comic media in learning Physics which is applied with features of humor, narration, and visual representations so that comics have a strong appeal to students.

Comic media in physics learning was also chosen as a means to improve critical thinking skills because it contains storylines in everyday life, is related to learning Physics, is accompanied by funny pictures or pictorial figures, and is packaged uniquely and attractively so that it makes students interested so that making students' reading interest higher. Comics in physics learning also make students think more imaginatively when seeing characters and stories in Comic Physics, and it is hoped that it can foster students' interest in reading. The advantage of comic media in learning physics is that making comics in classroom learning can make students interested in enjoying physics learning, where comics can simplify difficult concepts while providing entertainment for students. The weakness of comic media in learning physics is that the learning process requires guidance from the teacher because students like to read comics, so they forget the material being taught. From this background, the researcher will study comic media in physics learning because many students do not apply critical thinking skills in solving problems and only need other people.

Many researchers have researched comics, but it is still minimal in improving critical thinking skills. Most of them only discuss the practicality of the media used in the learning process. So that with the method of selecting researchers will focus more on reviewing several articles. So in general, the background of this research is used to see reading media from critical thinking, practicality, and the effectiveness of comics in learning physics and the instruments used in physics learning research.

\section{RESEARCH METHOD}

\section{Type of Research}

This research uses the literature study method, where this study using data and information sourced from various sources from books, journals, encyclopedias, dictionaries, and magazines. Literature study can also be interpreted as a technique of collecting data by analyzing a book or literature related to the problem to produce information that will be used as the result of library research. A referance study is a way to collect the truth of a news story by searching for sources 
from libraries which include archives, books, newsletters, journals, and history (Mardalis, 1999). A literature study studies theoretically every phenomenon related to culture, values, and developing norms (Sugiyono, 2013). The data technique is done by analyzing books, looking for references, writings, and information related to problems (Nazir, 1998).

\section{Research Procedures}

The research procedure used in the literature study According to Kuhlthau, there are several steps taken, namely selecting topics, exploring information, determining research focus, collecting data sources, preparing data presentation, and preparing reports. The following is a chart in the library research procedure, namely:

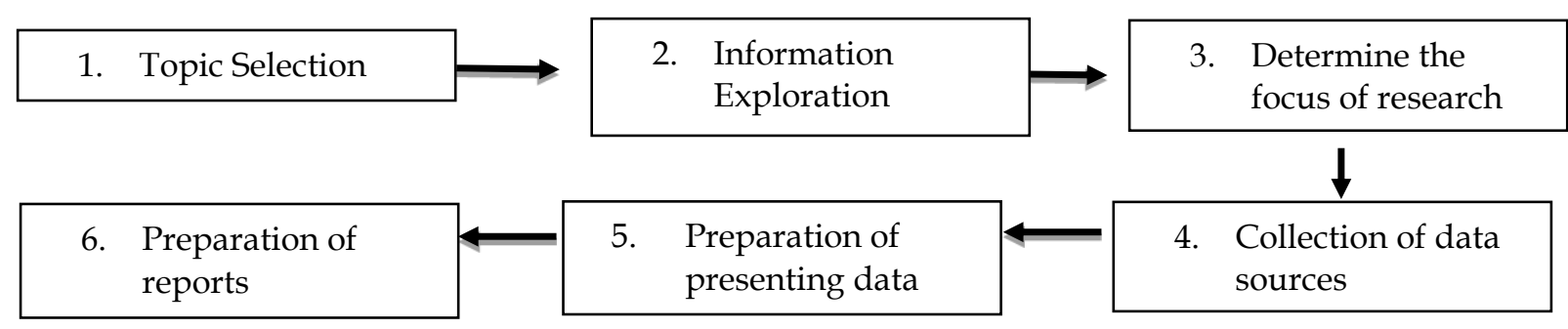

Figure 1. Library Research Chart

\section{Data Collection Techniques}

In literature research, data collection techniques in this study used secondary data. According to Suliyanto, Secondary data is information obtained unsustainably from the subject of analysis. secondary data already accumulated and shown by other parties for specific purposes. Secondary data used in this data collection research is in the form of documents by looking at the variables and subjects studied from national and international journals related to critical thinking and comic media Physics and sources from web pages analyzed and presented concisely and clearly.

\section{Data Analysis Techniques}

Data analysis techniques using descriptive qualitative analysis. In this qualitative approach, the experimental method was carried out by applying descriptive data, namely in recorded or spoken form sentences from the results of the literature study that has been carried out. Identifying comics to practice students' critical thinking skills in Physics education can be found in several research journals relevant to their fields. Each literature is content and serves as an object to obtain valid information and can be examined in detail according to a predetermined context. The content analysis procedure that is carried out aims to provide facts or phenomena studied (Nursalim, 2020). Then analyze to find information and conclusions from this literature study.

\section{RESULTS AND DISCUSSION}

From the articles that have been selected and adjusted to the research field, namely articles on critical thinking and comics then the point of discussion will be analyzed how the instruments, data analysis, and research methods are used in the article. One article will be analyzed and followed by other articles. In analyzing it will use qualitative methods. The following is a table to make it easier to analyze the relationship between comic media and critical thinking skills. 
Table 1. Sample journal articles on the relationship between comic media and critical thinking skills.

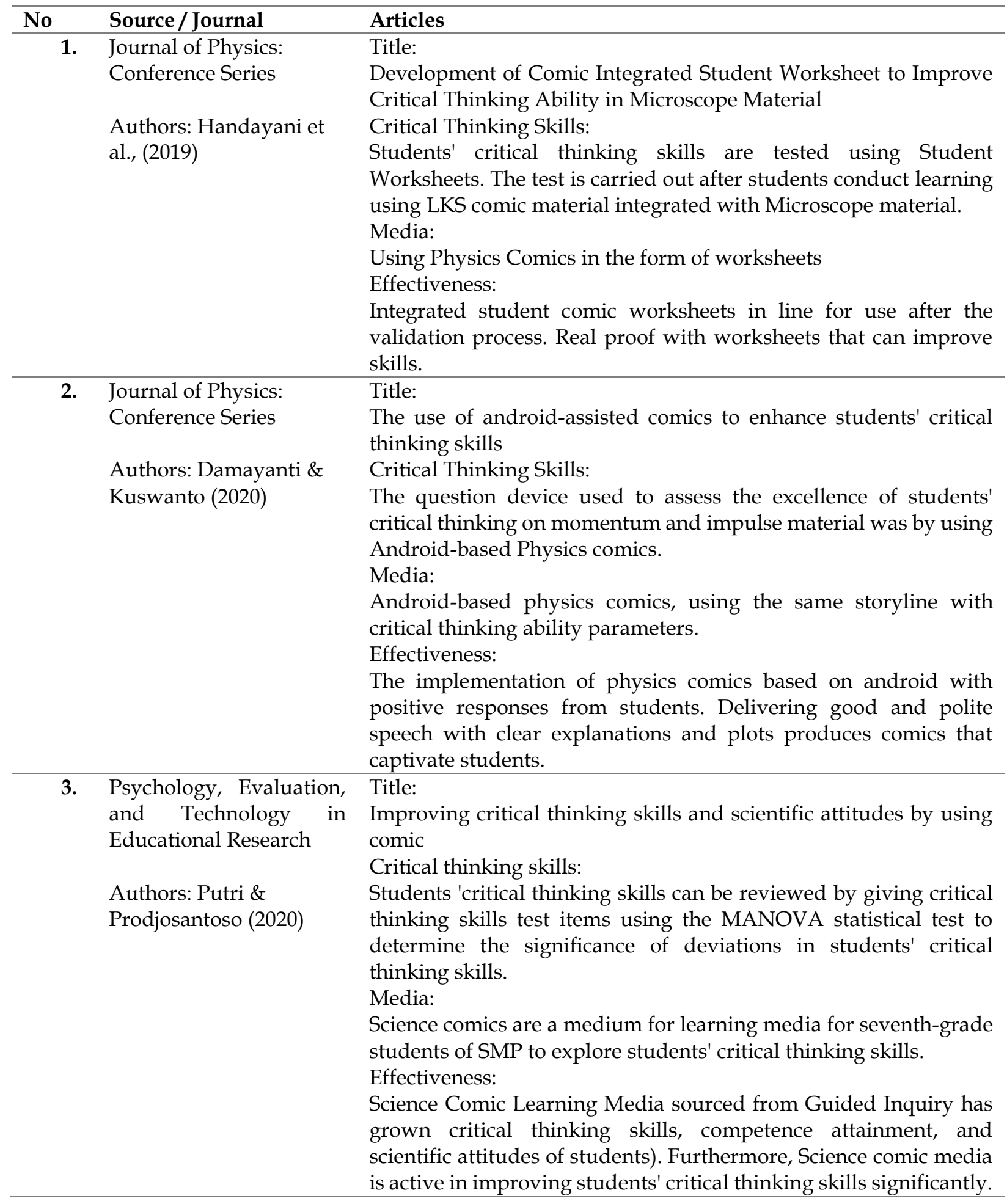

On the example of journal articles related to comics and critical thinking skills from Dinda Putri Handayani et al with the title "Development of Comic Integrated Student Worksheet to Improve Critical Thinking Ability in Microscope Material", the problems obtained include: How Integrated comic worksheets can measure critical thinking skills in microscope material. In solving these problems, the researcher used the Research and Development (R\&D) research and development procedure and the 4-D development reference, consisted of the Define, Design, Develop, and Disseminate stages. The research participants consisted of 15 students of class XII 
and 32 students of class XI as the subject of the trial. The media used is Physics Comics in worksheets. Critical thinking skills are estimated with Student Worksheets. The test will be fulfilled when the student has finished studying with LKS comic material on the worksheets combined with the microscope material

Based on examples of journal articles about relationships from comics and critical thinking skills from AE Damayanti and H Kuswanto with the title "The use of android-assisted comics to enhance students 'critical thinking skills", there are problems, including to understand the motive for developing students' critical thinking skills through comic physics sourced on android. In solving the research problem, the method used is qualitative as the data collection process. Participation in the study involved a sampling of 44 students. This experiment was carried out with two experimental classes. The media used is using android comics on momentum and impulse material. The pre-learning ability analysis was carried out before the android comic media was used by using the pretest question instrument at the beginning of the lesson and the posttest analysis of the ability after learning was done by giving posttest questions.

In the third journal review entitled "Improving critical thinking skills and scientific attitudes by using comics", the researcher used the Research and Development (R\&D) method. Science Comic media development as learning media for seventh-grade junior high school students to develop students' critical thinking skills. The subjects used in this experiment comes from seventh-grade junior high school students. The instrument for collecting data on critical thinking skills already operated in this study consists of test items for critical thinking skills.

Sourced from the results of the reviewing a sample of journal articles related to comic media with critical thinking skills in table 1, it was found that the average use involved 15-44 students with two experimental classes. Students' critical thinking skills are measured using different instruments, namely using Student Worksheet Tests and pretest and posttest questions. However, the media used remains the same, namely using comic book media. Most of them use android as a supporting medium of comic display. Learning is conducive because the packaging of comic media made verbally with a narrative and directed plot makes comics more exciting, and students are more enthusiastic than traditional learning.

Table 2. Sample journal articles on comic media

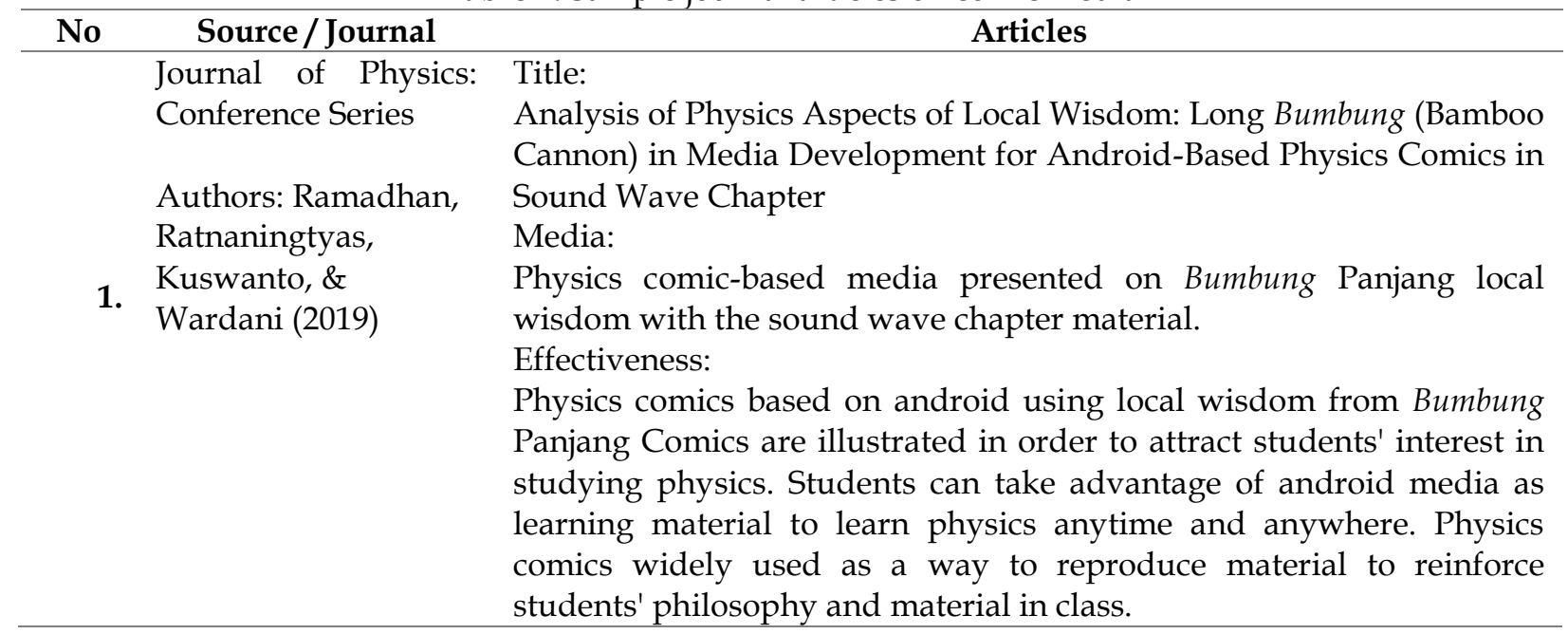




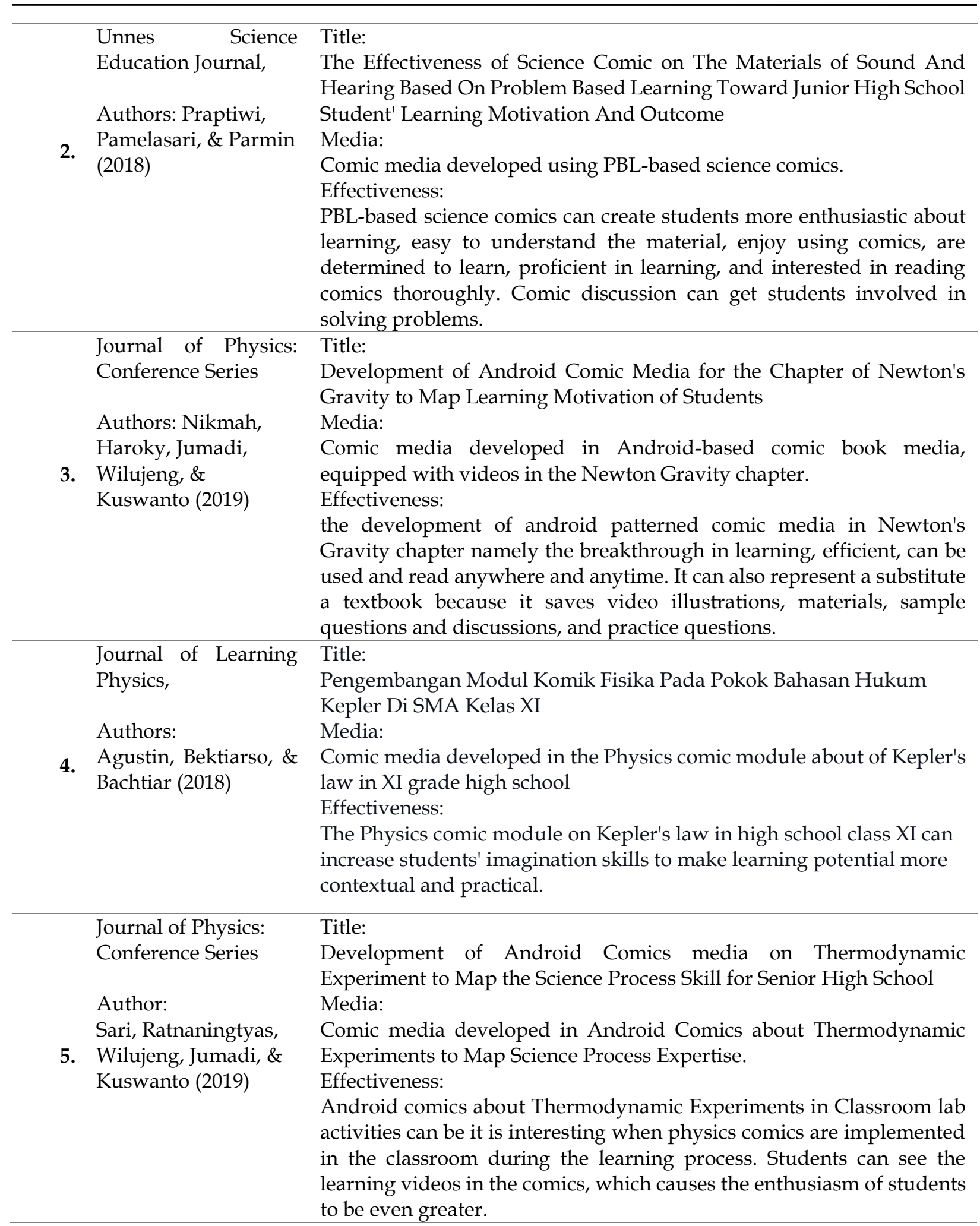

In the research article with a sample journal on comic media with the title "Analysis of Physics Aspects of Local Wisdom: Long Bumbung (Bamboo Cannon) in Media Development for Android-Based Physics Comics in Sound Wave Chapter", researchers in solving these problems used the Research and Development (R\&D) uses 4-D which consists the Define, Design, Develop and Disseminate stages. The article is presented with a comic design wearing way by determining and designing the stage, which was spelled out according to the local wisdom of Bumbung Panjang with the sound wave chapter material. This study's participation was the 11th-grade 
students in the physics class, but the number was not stated. This experiment aims to hone HOTS skills and students' physical representations of sound material.

Then in the review of the second article entitled "The Effectiveness Of Science Comic On The Materials Of Sound And Hearing Based On Problem Based Learning Toward Junior High School Student 'Learning Motivation And Outcome", researchers used experimental methods with quasi-experimental designs. Comic media developed using PBL-based science comics. Participation in this experiment used all students of class VIII Junior High School. The data analysis in this experiment used the normality and homogeneity of the pretest and post-test data. The test is used to obtain information about students' cognitive improvement.

As for the review of the third article entitled "Development of Android Comic Media for the Chapter of Newton's Gravity to Map Learning Motivation of Students", the researcher used the ADDIE method (Analysis, Design, Development, Implementation, and Evaluation), this comic developed in the form of a physics comic, which is accompanied by a video on Newton's Gravity chapter. Comics can be read anywhere with the Himawari Rider application on a smartphone or Android. The research subjects consisted of 18 high school students. The analysis is made by analyzing students, curriculum, and material.

Reviewing the fourth article from Agustin, Bektiarso, and Bachtiar with the title "Development of the Physics Comic Module on the Subject of Kepler's Law in Class XI Senior High School", the researcher used the Development method developed by Borg and Gall with direct modification of doing comic physics modules. The comic was developed in the Physics comic module on Kepler's law in XI grade high school. The subjects consisted of 21 students of class XI Science. The analysis was carried out by giving pretest questions before learning to ensure the improvement of students' physics learning outcomes after using the comic module.

In the fifth article review entitled "Development of Android Comics media on Thermodynamic Experiment to Map the Science Process Skill for Senior High School", researchers used the development method used, namely the Borg and Gall Research and Improvements, consisting of a preliminary, literature reviews, and implementation of field survey. The concept of physics comic media was developed based on Android on thermodynamic materials made using the Sigil application. Subjects were taken from class XI Science students. The method used is descriptive qualitative analysis, namely data analysis in the form of qualitative descriptive about the meaning of the research data. Data found from experiments while studying thermodynamics practicum.

Based on table 2, the average comic media is packaged with different concepts according to the researcher's needs. It proves that comic media is beneficial if used in the learning process; that is, it can adapt to the field conditions. Most comic media use a development method where researchers want to create a comic appearance that is more attractive and different from comics on the market and is presented based on Android which is very easy to reach and can be used whenever and wherever they are. That way comics are very useful as media in learning.

Table 3. Sample journal articles on critical thinking skills

\begin{tabular}{|c|c|c|}
\hline No & Source / Journal & Articles \\
\hline \multirow{6}{*}{1.} & Journal of Physics: & Title: \\
\hline & Conference Series & The Effect of Inductive Learning Model Assisted Mind map Mindjet \\
\hline & & Mind manager towards Critical Thinking Skills of Students \\
\hline & Authors: & Critical thinking skills: \\
\hline & Barra, Wilujeng, \& & The data collection techniques using research include, namely : \\
\hline & Kuswanto (2019) & $\begin{array}{l}\text { - the pretest and posttest questions in the form of a description } \\
\text { of the optical eye topic, } \\
\text { - amounting to four items to measure critical thinking skills in } \\
\text { providing simple explanations, } \\
\text { - concluding, and }\end{array}$ \\
\hline
\end{tabular}




\begin{tabular}{|c|c|c|}
\hline & & $\begin{array}{l}\text { - developing strategies and tactics. } \\
\text { Effectiveness: } \\
\text { After the pretest and posttest questions were carried out, there is } \\
\text { variations in students' critical thinking knowledge between before and } \\
\text { after being given the MindJet MindManager mindmap assisted } \\
\text { inductive learning model, namely the critical thinking ability } \\
\text { successfully improved. }\end{array}$ \\
\hline \multirow[t]{8}{*}{2.} & Universal Journal of & Title: \\
\hline & Educational & $\begin{array}{l}\text { The Effect of Ethno Science-Based Direct Instruction Learning Model in } \\
\text { Physics Learning on Students' Critical Thinking Skill }\end{array}$ \\
\hline & Authors: & Critical thinking skills: \\
\hline & Risdianto, Dinissjah, & The critical thinking skills test is given by giving pre-test questions and \\
\hline & Nirwana, \& & $\begin{array}{l}\text { after being given the treatment of post-test questions in classes that } \\
\text { have been carried out experiments which apply the Ethno-based Direct }\end{array}$ \\
\hline & & Instruction Learning Method. \\
\hline & & Effectiveness: \\
\hline & & $\begin{array}{l}\text { The Ethno-science-based Direct Instruction Learning Model's } \\
\text { application affects critical thinking skills because the learning model } \\
\text { connects classroom learning with students' daily lives and motivates } \\
\text { students to participate in the learning process actively. }\end{array}$ \\
\hline \multirow[t]{6}{*}{3.} & Journal of Physics: & Title: \\
\hline & Conference Series & Effectiveness of guided inquiry learning model to improve students' \\
\hline & Nisa, Koestiari , & Critical thinking skills: \\
\hline & $\begin{array}{l}\text { Habibbulloh \& } \\
\text { Jatmiko (2018) }\end{array}$ & $\begin{array}{l}\text { The test used to measure critical thinking skills is carried out by giving } \\
\text { questions (pre-test) to physics subjects on the topic of static fluids and } \\
\text { after learning the same (post-test) questions are also given. The critical } \\
\text { thinking skills test consists of } 10 \text { questions in the form of descriptions } \\
\text { (narrative) }\end{array}$ \\
\hline & & Effectiveness: \\
\hline & & $\begin{array}{l}\text { Learning with the guided learning model is very conducive to } \\
\text { developing critical thinking skills of class XSMA students, as evidenced } \\
\text { by the substantial increase in the average score of students' critical } \\
\text { thinking skills before and after learning. }\end{array}$ \\
\hline
\end{tabular}

In research articles with journal samples on critical thinking skills with the title "The Effect of Inductive Learning Model Mindjet Assisted Mindmanager towards Critical Thinking Skills of Students", researchers solve these problems using the one-group pretest-posttest design method as a strategy in research that aims to solve the problem-comparing the conditions of the group between before being given treatment and after being given treatment. This experiment only uses one class as a research subject because of the school policy. After the pretest and posttest questions were carried out, there are various critical thinking skills that students have between before and after being given the MindJet MindManager mindmap assisted inductive learning model, namely the critical thinking ability successfully improved.

Reviewing the second article entitled "The Effect of Ethno Science-Based Direct Instruction Learning Model in Physics Learning on Students' Critical Thinking Skill", the researcher used a quasi-experimental research method in which no group was randomly drawn. In this analysis using the non-equivalent control group creation, namely the experimental group and the control group were not randomly selected. The subjects used in this exploration were all students from class XI Science. Data analysis using the critical thinking ability test was carried out by giving pretest questions and after being given posttest question treatment in the experimental class that applied Ethno-based Direct Instruction Learning Model. 
In the review of the third article from Nisa, Koestiari, Habibbulloh, and Jatmiko with the title "Effectiveness of guided inquiry learning model to improve students' critical thinking skills at senior high school", the researcher used a pre-experimental method with a one-group pretest design and posttest. The pretest and posttest scores in physics subjects on the topic of the inquiry model were obtained through observations on static fluid material. The subjects used were taking three classes $X$ science. Data analysis using pretest and posttest questions of the guided inquiry fluid static model increased critical scores-students' thinking skills with a consistent improvement level.

Based on table 3, which is drawn from 3 samples of research articles on critical thinking skills, the average research procedure is one group pretest and posttest. The subjects used an average of 1-3 classes. Exploration in used to see how practical and efficient students' critical thinking skills were in learning - the evidence gave pretest questions before being given treatment and given posttest questions after being given treatment. The results obtained said that after giving the pretest questions and after being given the treatment of the posttest question, students' critical thinking skills increased and were consistent. So that critical thinking skills can be effectively used in learning.

From the review of eleven articles on Comics and Critical Thinking, on average, using the development method and one group pretest and posttest. The study consisted of 15 students to 90 students, who were on average taking a sample of 1-3 science classes, both class VII Junior High School and class X, XI Senior High School Science. Then the instrument mostly uses pretest questions before being given treatment and posttest questions after being given treatment. However, some use practicum observations in the lab.

Comic physics media to improve critical thinking skills uniquely brings students to learn fun in a class by providing comic media concepts that are packaged by applying daily life, applying local wisdom around the school environment. Therefore, they can adjust the classroom situation by applying learning models such as PBL, Inquiry, and Direct Instruction. Students can be comfortable learning in class, starting from learning science subjects in junior high school classes to physics subjects in High School classes, which are considered difficult and tedious because there are many formulas used. That way, students become excited about learning plus comic media based on android so that they can be accessed anytime and anywhere without having to bring textbooks.

\section{CONCLUSION}

Based on the research criteria that have been reviewed and the contents of eleven articles were selected, the conclusions can be drawn from how the researcher can make critical thinking skills, the media used, and the effectiveness. Through a sample selection of several articles, three articles about the relationship between comic media and critical thinking skills were obtained, five articles related to comic media, and three articles related to critical thinking skills. Second, from the results of eleven review articles, the number of participants or respondents used ranged from 15 students to 90 students, where the average sample was 1-3 science classes, from grade VII Junior High School to class X and XI Senior High School Science. The three overall methods used are the development method and the one group pre-test and post-test method. Comic media can also apply critical thinking skills in the laboratory, not only in the classroom to the learning process.

\section{ACKNOWLEDGEMENTS}

Thanks to all reviewers who with all the time and expertise to review and evaluate and help us in finalization of this scientific article. 


\section{REFERENCES}

Af'idah, I., \& Kustijono. R. (2019). Keefektifan mobile learning untuk melatih keterampilan berpikir kritis siswa SMA. Prosiding Seminar Nasional Fisika (SNF) Unesa 2020, 3, 39-43.

Agustin, H. A., Bektiarso, S., \& Bachtiar, R. W. (2018). Pengembangan modul komik fisika pada pokok bahasan hukum Kepler di SMA kelas XI. Jurnal Pembelajaran Fisika, 7(2),168-174.

Aisyah, R., Zakiyah, I. A., Farida, I., \& Ramdhani, M.A. (2017). Learning crude oil by using scientific literacy comics. International Conference on Mathematics and Science Education (ICMScE) IOP Conf. Series: Journal of Physics, 895(1), 1-7.

Amalia, F. R., \& Kustijono, R. (2019). Pengembangan e-Book Fisika menggunakan sigil untuk melatihkan keterampilan berpikir kritis siswa SMA. Jurnal Inovasi Pendidikan Fisika (JIPF), 8(1), 465-469.

Anisa, S.N., \& Kustijono, R. (2018). Keefektifan animated simulation book (As Book) untuk melatihkan keterampilan proses sains dasar dalam pembelajaran fisika. Jurnal Inovasi Pendidikan Fisika, 7(2), 263-267.

Barra, W. N., Wilujeng, I., \& Kuswanto., H. (2019). The effect of Inductive learning model assisted Mindmap Mindjet Mindmanager towards Critical Thinking Skills of Students. Journal of Physics: Conference Series, 1233(1), 1-12.

Damayanti, A. E. \& Kuswanto, H. (2020). The use of android-assisted comics to enhance students' critical thinking skill. Journal of Physics: Conference Series, 1440 (1), 1-7.

Fatimah, F., \& Widiyatmoko. (2014). Pengembangan science comic berbasis problem based learning sebagai media pembelajaran pada tema bunyi dan pendengaran untuk siswa SMP. Jurnal Pendidikan IPA Indonesia (JPII), 3(2), 146-153.

Hadiati, S., Kuswanto, H., Rosana, D., \& Pramuda., A. (2019). The comprehensive physics laboratory work with model-based reasoning to improve 21st-century competence. Journal of Physics: Conference Series, 1185(1), 1-7.

Handayani, D. P., Jumadi, Wilujeng, I., \& Kuswanto, H. (2019). Development of comic integrated student worksheet to improve critical thinking ability in microscope material. Journal of Physics: Conference Series, 1233(1), 1-8.

Hanke, J.E., \& Reitsch, A.G. (1998). Business Forecasting. Sixth Edition. London: Prentice-Hall International Ltd.

Indriani, M., \& Kholiq, A. (2019). Validitas perangkat pembelajaran model diskusi berbasis ECT (E-Book Crictical Thinking). Jurnal IPF: Inovasi Pendidikan Fisika, 8(3), 895-897.

Iqliya, J. N., \& Kustijono, R. (2020). Media interaktif augmented reality untuk melatihkan keterampilan proses sains siswa SMA. Jurnal IPF: Inovasi Pendidikan Fisika, 9(2), 265-270.

Jamaluddin, D., Ratnasih, T., Gunawan H., \& Paujiah, E. (2020). Pembelajaran daring masa pandemik Covid-19 pada calon guru: Hambatan, solusi dan proyeksi. Digital Library UIN Sunan Gunung Djati, 1-10.

Lestari, I., Wahyuni, S., \& Yushardi. (2016). Pengembangan bahan ajar IPA berbasis komik pada pokok bahasan gerak di SMP. Prosiding Seminar Nasional Pendidikan Fisika, 4(5), 564-572.

Lestari, P. D., Dwijanto, P., \& Hendikawati. (2016). Keefektifan model problem-based learning dengan pendekatan saintifik terhadap kemampuan pemecahan masalah dan kemandirian belajar peserta didik kelas VII. Unnes Journal of Mathematic Education, 5(2), 146-153.

Mardalis. (1999). Metode Penelitian Suatu Pendekatan Proposal. Jakarta: Bumi Aksara.

Mirzaqon, A. \& Purwoko, B. (2018). Studi kepustakaan mengenai landasan teori dan praktik konseling expressive writing. Library Research of The Basic Theory and Practice of Experessive Writing Counseling, 8(1), 1-8.

Nazir. (1998). Metode Penelitian. Jakarta: Ghalia Indonesia.

Nikmah, S., Haroky, F., Jumadi., Wilujeng, I., \& Kuswanto, H. (2019). Development of android comic media for the chapter of Newton's gravity to map learning motivation of students. Journal of Physics: Conference Series, 1233(1), 1-10. 
Nisa E. K., Koestiari, T., Habibbulloh, M., \& Jatmiko, B. (2018). Effectiveness of guided inquiry learning model to improve students' critical thinking skills at senior high school. Journal of Physics: Conference Series,1742-6596.

Putri, M. A., \& Prodjosantoso, A. K. (2020). Improving critical thinking skills and scientific attitudes by using comic. Psikologi, Evaluasi, dan Teknologi dalam Penelitian Pendidikan, 2(2), 6980.

Praptiwi, U. S., Pamelasari, S. D., \& Parmin. (2018). The effectiveness of science comic on the materials of sound and hearing based on problem based learning toward junior high school student' learning motivation and outcome. Unnes Science Education Journal, 7(1), 111-118.

Qibtiya, M., \& Kustijono, R. (2018). Keefektifan penggunaan e-book untuk melatihkan keterampilan berpikir kritis. Prosiding Seminar Nasional Fisika, 2(1).

Rahma, A. N. (2012). Pengembangan perangkat pembelajaran model inkuiri berpendekatan SETS materi kelarutan dan hasil kali kelarutan untuk menumbuhkan keterampilan berpikir kritis dan empati siswa terhadap lingkungan. Journal of Educational Research and Evaluation, 1(2), 133-138.

Rahmawati, L., Subanji., \& Afifah, D. S. N. (2019). Analysis of critical thinking from student with quantitative approach. Journal of Physics: Conference Series, 1339(1), 1-4.

Ramadhan, R.H., Ratnaningtyas, L., Kuswanto, H., \& Wardani, R. (2019). Analysis of physics aspects of local wisdom: Long Bumbung (Bamboo Cannon) in media development for android-based physics comics in sound wave chapter. Journal of Physics: Conference Series, 1397(1),1-8.

Rasiman., \& Pramasdyahsari, A.S. (2014). Development of mathematics learning media e- comic based on flipbook maker to increase the critical thinking skill and character of junior high school students. Jurnal Internasional Pendidikan dan Penelitian, 2(11), 535-544.

Risdianto, E., Dinissjah, M. J., Nirwana., \& Kristiawan, M. (2020). The effect of ethno sciencebased direct instruction learning model in physics learning on students' critical thinking skill. Universal Journal of Educational Research, 8(2), 611-615.

Sugiyono. (2013). Metode penelitian pendidikan pendekatan kuantitatifkualitatif, dan $R \mathcal{E} D$. Bandung: Alfabeta.

Umar, L. M., \& Nursalim, M. (2020). Studi kepustakaan tentang dampak wabah Covid-19 terhadap kegiatan belajar mengajar pada siswa Sekolah Dasar (SD). Jurnal BK Unesa, 11(4).

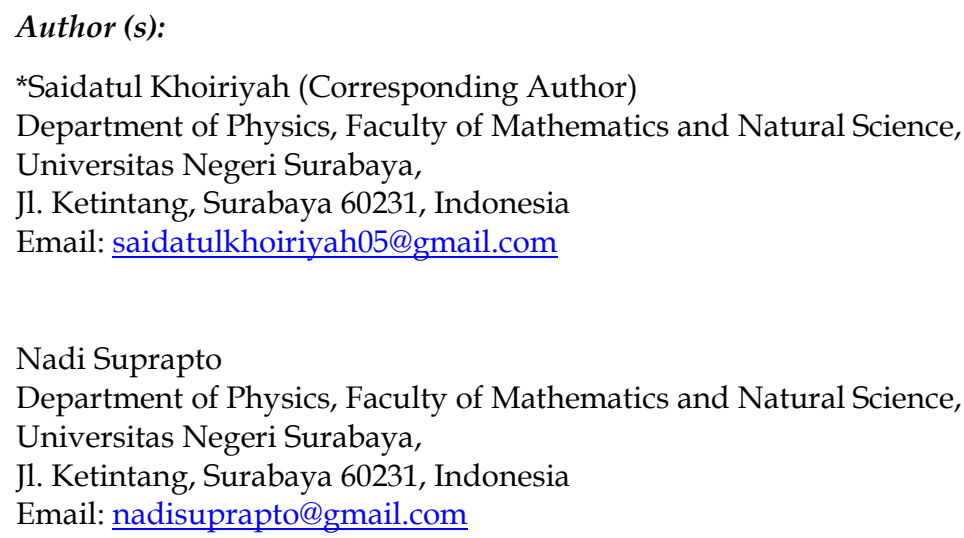

